\title{
The Cellulase System of Cellulomonas fimi
}

\author{
By MAUREEN L. LANGSFORD, N. R. GILKES, W. W. WAKARCHUK, \\ D. G. KILBURN, R. C. MILlER, JR AND R. A. J. WARREN* \\ University of British Columbia, Department of Microbiology, Vancouver, British Columbia, \\ Canada V6T 1W5
}

(Received 13 October 1983; revised 20 January 1984)

\begin{abstract}
Supernatants from cultures of Cellulomonas fimi contained up to 10 components with CMcellulase activity as determined by non-denaturing PAGE. Some of the active components were glycosylated. The activity profiles of the supernatants, as determined by PAGE, varied with the cellulosic substrate used for the growth of a culture, with culture age, and with storage of the supernatants. These variations were a consequence of proteolysis and a reduction in the glycosylation of some of the components. Proteinase activity in the supernatants was induced by growth of $C$. fimi on cellulosic substrates. Proteolysis and a reduction in glycosylation resulted in the conversion of slow-moving into fast-moving components on non-denaturing PAGE. The fast-moving components had a reduced ability to bind to an insoluble cellulosic substrate such as Avicel. Several of the CM-cellulase activities in culture supernatants were immunologically related. In contrast to the large number of CM-cellulases found in the supernatant, substratebound activity comprised only three slow-moving components, at least some of which were glycosylated. It was concluded that the cellulase system of $C$. fimi was composed of only three enzymes, and that these enzymes had a great affinity for, and were stabilized by binding to, an insoluble cellulosic substrate. Enzymes which accumulated free in the culture medium were subject to limited proteolysis and de-glycosylation which generated a variety of products, some of which retained enzymic activity.
\end{abstract}

\section{INTRODUCTION}

Many micro-organisms secrete cellulases under appropriate conditions, thereby allowing the utilization of cellulose as a carbon source. The rate of cellulolysis for a given organism is limited by several factors, including the nature and amounts of the enzymes secreted, the sensitivities of the enzymes to end-product inhibition, and the nature of the cellulosic substrate. Consequently, the rate of degradation of cellulose may be increased in a variety of ways. Pretreatment of natural materials such as sawdust and straw can render the cellulose within them more susceptible to cellulases (Millett et al., 1976). Alternatively, mutants with an improved ability to degrade cellulose can be isolated from a given organism. In strains of Cellulomonas, for example, mutants have been isolated which are more efficient than the parent strains in the degradation of crystalline cellulose. These can be resistant to catabolite repression (Stewart \& Leatherwood, 1976), end-product inhibition (Choudhury et al., 1980), or can produce increased levels of cellulases (Choi et al., 1978).

Gene cloning affords another approach to increasing cellulase production. In theory, substantial increases in enzyme levels should be possible by this means. The cellulase systems produced by different organisms vary in their efficiency either because of the catalytic properties of the enzymes themselves or because of the proportions of the different enzymes within a given system. Gene cloning would allow the construction of strains producing altered

Abbreviations: HAT, hypoxanthine, aminopterin and thymidine; PMSF, phenylmethylsulphonyl fluoride. 
proportions of the enzymes within a system or enzymes originating from more than one organism. Recently, as a first step towards this end, we reported the cloning of a Cellulomonas fimi cellulase gene in Escherichia coli (Whittle et al., 1982). The successful reconstruction by molecular genetics of the entire $C$. fimi cellulase system depends on an understanding of the structural genes involved. Although the genetics of $C$. fimi is essentially unknown, enumeration of the enzymes in the system should indicate the critical number of genes.

Cellulomonas strains produce several different cellulases (Beguin \& Eisen, 1978; Haggett et al., 1979) but the true nature of the system has not been investigated in detail. PAGE has been used very effectively to analyse the cellulase system of Acetivibrio cellulolyticus (Saddler \& Khan, 1981). In this paper we describe the analysis of the extracellular cellulase system of $C$. fimi by PAGE.

\section{METHODS}

Growth of cultures. Cellulomonas fimi ATCC 484 was grown in basal salts medium (Whittle et al., 1982) supplemented with $0.1 \%$ glucose, $0.1 \%$ CM-cellulose or $0.1 \%$ Avicel. Stocks were maintained by making exponential cultures $1 \%$ in DMSO, and freezing samples at $-70^{\circ} \mathrm{C}$.

Enzyme assays. Cellulase activity was assayed by measuring the reducing groups released from CM-cellulose (Stewart \& Leatherwood, 1976). Reaction mixtures contained $0.5 \mathrm{ml}$ of appropriately diluted enzyme preparation and $1.0 \mathrm{ml} 4 \%$ (w/v) CM-cellulose in $50 \mathrm{mM}$-sodium/potassium phosphate buffer, $\mathrm{pH} 6.8$. The reactions were stopped by the addition of $1.5 \mathrm{ml} 3,5$-dinitrosalicylic acid reagent (Miller, 1959). The tubes were covered and placed in boiling water for $15 \mathrm{~min}$. The absorbance values at $550 \mathrm{~nm}$ were read against blanks containing equivalent amounts of boiled enzyme. Glucose equivalents were obtained by reference to a standard curve. One unit of enzyme released reducing groups equivalent to $1 \mu \mathrm{g}$ glucose $\min ^{-1}$. Proteinase activity was measured by the hide powder blue assay (Rinderknecht et al., 1968).

Electrophoretic analysis of culture supernatants. Cells and undegraded Avicel were removed from cultures by centrifugation for $20 \mathrm{~min}$ at $10000 \mathrm{~g}$ and $4{ }^{\circ} \mathrm{C}$. The supernatants were concentrated by ultrafiltration through Amicon PM10 membranes. Samples were electrophoresed in either non-denaturing (Jovin et al., 1964) or SDScontaining (Laemmli, 1970) polyacrylamide slab gels $1.5 \mathrm{~mm}$ thick. Two-dimensional gels were run according to the procedure of $O^{\prime}$ Farrell $(1975)$ except that the first dimension was a non-denaturing $6 \%(\mathrm{w} / \mathrm{v})$ polyacrylamide slab gel. Gels were stained for protein with Coomassie blue (Schleif \& Wensink, 1981) and for glycoproteins with fuchsin (McGuckin \& McKenzie, 1958; Zacharius et al., 1969). Cellulase activity in a gel was detected as follows: a lane was excised from the gel and cut into $2 \mathrm{~mm}$ slices; each slice was incubated with $0.5 \mathrm{ml} 50 \mathrm{~mm}$-phosphate

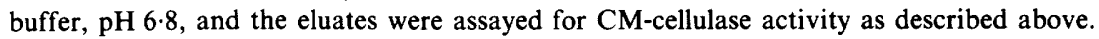

Binding of proteins to concanavalin A-Sepharose. The supernatant from a $250 \mathrm{ml}$ culture grown for $3 \mathrm{~d}$ on $0.1 \%$ Avicel was concentrated 100-fold by ultrafiltration through an Amicon PM10 membrane. A 0.15 ml sample of the concentrate was applied to a column $(1.5 \times 3.0 \mathrm{~cm})$ of concanavalin A-Sepharose 4B (Pharmacia). The column was washed with 10 column volumes of $20 \mathrm{~mm}-\mathrm{Tris} / \mathrm{HCl}, 50 \mathrm{mM}-\mathrm{NaCl}, \mathrm{pH} 7 \cdot 4$. The washings were concentrated by ultrafiltration to give fraction 1 . Proteins bound to the column were eluted with $60 \mathrm{ml} 0 \cdot 1 \mathrm{M}-\alpha$-methylglucoside in the same buffer. The eluate was concentrated to give fraction 2.

Release of substrate-bound enzymes. A 1 litre culture grown on Avicel for $6 \mathrm{~d}$ was left at $4^{\circ} \mathrm{C}$ overnight. The supernatant was decanted and the Avicel was resuspended in 1 litre of ice-cold $10 \mathrm{mM}$-Tris/ $\mathrm{HCl}, \mathrm{pH} 7 \cdot 0$. The Avicel was allowed to settle for $2 \mathrm{~h}$ at $4{ }^{\circ} \mathrm{C}$. The supernatant was decanted and the Avicel was resuspended in $500 \mathrm{ml}$ of ice-cold Tris $/ \mathrm{HCl}, \mathrm{pH} 7 \cdot 0$, containing $0.1 \%$ sodium azide (TA buffer). The suspension was centrifuged at $300 \mathrm{~g}$ for $5 \mathrm{~min}$ at $4{ }^{\circ} \mathrm{C}$, and the supernatant decanted. The pellet was resuspended in $200 \mathrm{ml} \mathrm{TA}$ buffer, and the suspension was centrifuged at $6000 \mathrm{~g}$ for $10 \mathrm{~min}$ at $4^{\circ} \mathrm{C}$. The pellet was resuspended in $200 \mathrm{ml} 10 \mathrm{mM}$-Tris/ $\mathrm{HCl}$, $2 \mathrm{M}-\mathrm{NaCl}, 0.01 \%$ sodium azide, $\mathrm{pH} 7.0$ (TNA buffer), and the suspension centrifuged at $6000 \mathrm{~g}$ for $7 \mathrm{~min}$ at $4{ }^{\circ} \mathrm{C}$. The supernatant was decanted and saved as the $2 \mathrm{M}-\mathrm{NaCl}$ eluate. The pellet was washed by centrifugation in $200 \mathrm{ml} \mathrm{TA}$ buffer and then resuspended in $50 \mathrm{ml} 10 \mathrm{~mm}$-Tris/ $\mathrm{HCl}, 8 \mathrm{M}$-guanidine. $\mathrm{HCl}, \mathrm{pH} 7.0$ (TG buffer). After $10 \mathrm{~min}$ at room temperature the suspension was centrifuged at $1000 \mathrm{~g}$ for $5 \mathrm{~min}$ (room temperature). The supernatant was stored on ice, and the pellet was treated twice more with TG buffer as described above. The final pellet was discarded. The TG buffer eluates were combined and diluted to $500 \mathrm{ml}$ with TA buffer. This solution was filtered through a glass fibre filter and concentrated 10-fold by pressure filtration through an Amicon PM10 membrane. The solution was diluted to $500 \mathrm{ml}$ with TA buffer and concentrated again by filtration until a final concentration of less than $10^{-3} \mathrm{M}$-guanidine was obtained.

Monoclonal antibodies to $C$. fimi cellulases. BALB/c mice were injected subcutaneously with $0.1 \mathrm{ml}$ cellulasecontaining $C$. fimi supernatant emulsified in Freund's complete adjuvant. One month later the mice were injected intravenously with $0.1 \mathrm{ml}$ of the supernatant. After a further $3 \mathrm{~d}$, spleen cells were taken for fusion with the SP2 $/ 0$ myeloma cell line (from Dr T. W. Pearson, University of Victoria, Victoria, B.C., Canada) that is sensitive to 
medium containing hypoxanthine, aminopterin and thymidine (HAT). Polyethylene glycol-mediated fusion was performed by standard methods (Oi \& Herzenberg, 1980), and hybrid cells were selected on medium containing HAT in $2 \mathrm{ml}$ cultures. When growth was evident, the supernatants were tested using the ELISA method for antibodies binding specifically to cellulase-containing supernatants. Supernatant from a $C$. fimi culture grown for $3 \mathrm{~d}$ on $0.2 \%$ Avicel was diluted to $100 \mu \mathrm{g}$ protein $\mathrm{ml}^{-1}$ in sodium carbonate buffer $\mathrm{pH} \mathrm{9.0.} \mathrm{ELISA} \mathrm{plates} \mathrm{were}$ coated with this preparation by incubation overnight at $4{ }^{\circ} \mathrm{C}$. This plate coating had previously been shown to be optimal for the titration of rabbit antisera to the cellulase-containing supernatant. The binding of the monoclonals to proteins eluted from native PAGE gel slices was assessed by an analogous radioimmunoassay technique. Plates were coated with $10 \mu \mathrm{g}$ protein $\mathrm{ml}^{-1}$ in carbonate buffer as above and the bound monoclonal antibodies were detected with ${ }^{125} \mathrm{I}$-labelled $\mathrm{F}\left(\mathrm{ab}^{\prime}\right)_{2}$ rabbit anti-mouse $\mathrm{Ig}$. The plate coatings gave comparable positives for each antigen when a polyclonal rabbit antiserum was used. Positive cultures were cloned by limiting dilution and reassayed. Positive clones were recloned by limiting dilution.

Preparation of immunoadsorbent column. Ascites fluid containing monoclonal antibody A2/36.17.2 was precipitated with ammonium sulphate then resuspended and dialysed against $0 \cdot 1 \mathrm{M}$-sodium borate buffer, $\mathrm{pH} 8 \cdot 2$. Dialysed material $(2 \mathrm{ml})$ was cross-linked with dimethyladipimidate to $0.4 \mathrm{~g}$ Protein A-Sepharose C1-4B (Pharmacia) in $5 \mathrm{ml} \mathrm{0.1} \mathrm{M-sodium} \mathrm{borate} \mathrm{buffer,} \mathrm{pH} 8.2$ (Schneider et al., 1982). The immunoadsorbent was packed into a column $(1.0 \times 1.5 \mathrm{~cm})$ and washed exhaustively with $\mathrm{PBS}(137 \mathrm{~mm}-\mathrm{NaCl}, 2.7 \mathrm{mM}-\mathrm{KCl}, 1.7 \mathrm{~mm}-$

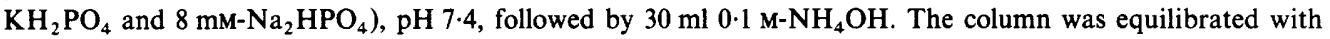
PBS, $\mathrm{pH} 7 \cdot 4$. Concentrated culture supernatant $(0 \cdot 1 \mathrm{ml})$ was loaded onto the column, and after $2 \mathrm{~h}$ at room

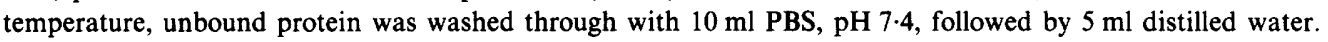
Bound proteins were eluted with $10 \mathrm{ml} 0 \cdot 1 \mathrm{M}-\mathrm{NH}_{4} \mathrm{OH}$. The eluate was lyophilized immediately and the residue resuspended in $50 \mathrm{~mm}$-phosphate buffer, $\mathrm{pH} 6 \cdot 8$.

\section{RESULTS}

\section{Effects of substrate on the cellulase system}

Non-denaturing PAGE of concentrated supernatants from C. fimi cultures revealed a complex mixture of proteins. Assay of gel slices revealed up to 10 discrete regions with CMcellulase activity. The activity profiles of supernatants from cultures grown with CM-cellulose or Avicel were different (Fig. 1). Because we are interested in enzymes acting on insoluble cellulose, we chose to work primarily with cultures grown on Avicel.

The CM-cellulase activity in culture supernatants declined at Avicel concentrations above $0.2 \%$, and was virtually undetectable at concentrations above $1-2 \%$ (Fig. 2). However, the protein concentrations in supernatants were similar at all concentrations of Avicel tested (Fig. 2).

The lack of CM-cellulase activity in the supernatants from cultures grown with $5 \%(\mathrm{w} / \mathrm{v})$ Avicel was probably the result of adsorption or binding of the cellulases to excess Avicel. Supernatants from a culture grown with $0 \cdot 1 \%$ Avicel lost $35-70 \%$ of their CM-cellulase activity when they were shaken with $5 \%$ Avicel for $20 \mathrm{~h}$ at $30^{\circ} \mathrm{C}$. The binding under these conditions was selective as revealed by non-denaturing PAGE (Fig. 3).

\section{Effects of culture age and storage on the cellulase system}

Total CM-cellulase activity in the supernatant increased throughout a $9 \mathrm{~d}$ incubation of a culture, but the rate of increase was not constant. Significantly, the amount of protein in the supernatant increased by only $25 \%$ from 3 to $9 \mathrm{~d}$ after inoculation, whereas the CM-cellulase activity increased by $100 \%$ (Fig. 2, curves for $0.2 \%$ Avicel).

The activity profiles varied with culture age, and there were corresponding changes in the polypeptide profiles (Fig. 4). Analysis of culture supernatants by two-dimensional gel electrophoresis revealed that there were multiple polypeptides in the non-denaturing gel bands. The major bands at the top of non-denaturing gels shifted to slightly more mobile bands as the cultures aged (Fig. 4). This was visualized in two-dimensional gels as a loss of a $56000 \mathrm{Dal}$ component and an increase in a 45000 Dal component. The $6 \mathrm{~d}$ culture supernatant showed this transition, because it had components observed in both $3 \mathrm{~d}$ and $9 \mathrm{~d}$ culture supernatants.

The total CM-cellulase activity of a given supernatant remained constant during several months storage at $4{ }^{\circ} \mathrm{C}$, although there were changes in the protein and activity profiles. The changes in both profiles involved the conversion of slow-moving to faster-moving components. 


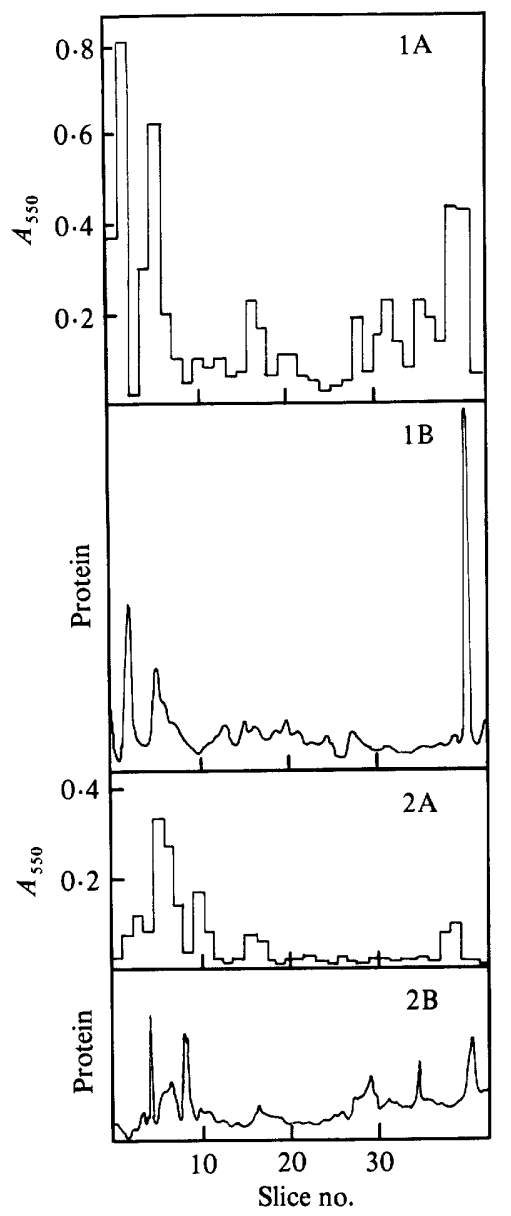

Fig. 1. CM-cellulase activities in supernatants from $C$. fimi cultures grown with different substrates. One culture was grown for $3 \mathrm{~d}$ with $0.1 \%$ Avicel (panel 1); another culture was grown for $3 \mathrm{~d}$ with $0 \cdot 1 \%$ CM-cellulose (panel 2). The cell-free culture supernatants obtained by centrifugation were concentrated by ultrafiltration. Samples of $35 \mu \mathrm{l}$ were electrophoresed in a $6 \%$ non-denaturing polyacrylamide slab gel $1.5 \mathrm{~mm}$ thick. After electrophoresis, one lane was excised from the gel and cut into $2 \mathrm{~mm}$ slices; each slice was eluted with $0.5 \mathrm{ml} 50 \mathrm{~mm}$-phosphate buffer, $\mathrm{pH} 6.8$. The eluates then were assayed for CMcellulase activity (panel A). A second lane was stained with Coomassie blue and scanned for protein (relative units; panel B).

These changes were prevented by the addition of a serine proteinase inhibitor, phenylmethylsulphonyl fluoride (PMSF), an indication that they were at least partly the result of proteinase activity. Analysis of the supernatants by SDS-PAGE showed also that storage resulted in the conversion of higher molecular weight polypeptides to lower molecular weight products.

\section{Proteinase activity in C. fimi culture supernatants}

The observed changes in the polypeptide and CM-cellulase activity profiles could have resulted from limited proteolysis. Cellulomonas fimi culture supernatants contained proteinase activity, and there appeared to be a relationship between the production of the cellulases and the proteinases, since glucose repressed the synthesis of both activities and cellulose induced them both (Table 1). The proteinase activity was inhibited $41 \%$ by $2 \mu \mathrm{g} \mathrm{PMSF} \mathrm{ml}{ }^{-1}, 86 \%$ by $10 \mu \mathrm{g} \mathrm{ml}^{-1}$, and $100 \%$ by $20 \mu \mathrm{g} \mathrm{ml}^{-1}$. 


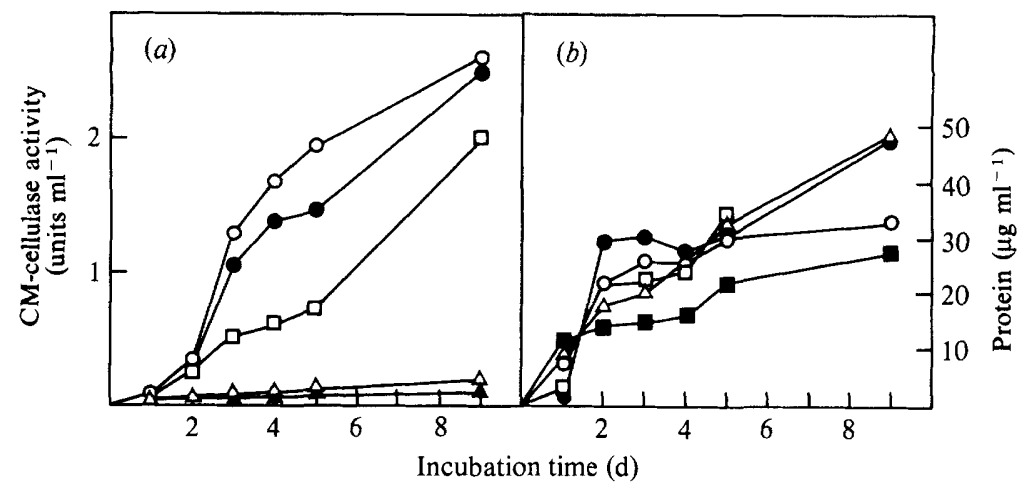

Fig. 2 Appearance of CM-cellulase activity during culture growth. Cultures were grown with different concentrations of Avicel. Samples were removed at intervals; cells and residual Avicel were removed by centrifugation. The supernatants were concentrated by ultrafiltration. Then they were assayed for protein and CM-cellulase activity, which is expressed as $\mu \mathrm{g}$ glucose equivalents released $\min ^{-1}(\mathrm{ml}$ original culture volume) ${ }^{-1}$. (a) CM-cellulase activity; $(b)$ protein concentration. Avicel concentrations were: $0.2 \%(\bigcirc), 0.5 \%(\bigcirc), 1.0 \%(\square), 3.0 \%(a, \Delta ; b, \square)$, and $5.0 \%(\triangle)$.

\section{Glycosylated proteins in C. fimi culture supernatants}

Many enzymes, including some cellulases (Beguin \& Eisen, 1978; Gum \& Brown, 1977; Berghem et al., 1976) are glycosylated. Culture supernatants of $C$. fimi contained glycoproteins, some of which corresponded to regions of cellulase activity in non-denaturing gels, but there were no glycosylated proteins in the region of the gel corresponding to the more mobile CMcellulase activities. This was confirmed by passage of a concentrated culture supernatant through a column of concanavalin A-Sepharose. The components of the system binding to the lectin corresponded to the slower-moving CM-cellulase activities.

\section{Substrate-bound enzymes}

Cellulases, including some of those from C. fimi (Beguin \& Eisen, 1978), bind tightly to the substrate. The lack of activity in supernatants from cultures grown with concentrations of Avicel greater than $1 \%$ (Fig. 2) suggested that all the components of the $C$. fimi complex could bind to the substrate.

The residual substrate in cultures grown for $6 \mathrm{~d}$ with $0.2 \%$ or $5 \%$ Avicel was washed free of cells and culture supernatant. CM-cellulase activity released from the Avicel with $8 \mathrm{M}$ guanidine. $\mathrm{HCl}$ was compared to activity in the culture supernatant by non-denaturing PAGE. A major and a minor band of activity, corresponding to a major and a minor band of protein, were released from the Avicel from the $0.2 \%$ culture (Fig. 5); the supernatant contained the usual complex mixture of proteins and activities. The same active bands were released from the Avicel from the $5 \%$ culture, again corresponding to two protein bands. The supernatant from the $5 \%$ culture contained very little activity, but the activity profile again was much more complex than that of the substrate-bound activity.

\section{Antigenic relatedness of $C M$-cellulase activities in culture supernatants}

Monoclonal antibodies were raised against a supernatant from a $3 \mathrm{~d}$ culture grown on $0.2 \%$ Avicel. The antibodies were tested for their capacity to bind the bands of CM-cellulase activity obtained from non-denaturing gels. Radioimmunoassay plates were coated with the proteins recovered from gel slices adjusted to $10 \mu \mathrm{g} \mathrm{ml}^{-1}$ in carbonate buffer, $\mathrm{pH} 9.0$. A series of monoclonal antibodies was then tested for binding to these antigens as assessed by the binding of an iodinated second antibody, the $F\left(a b^{\prime}\right)_{2}$ fragment of rabbit anti-mouse Ig. 


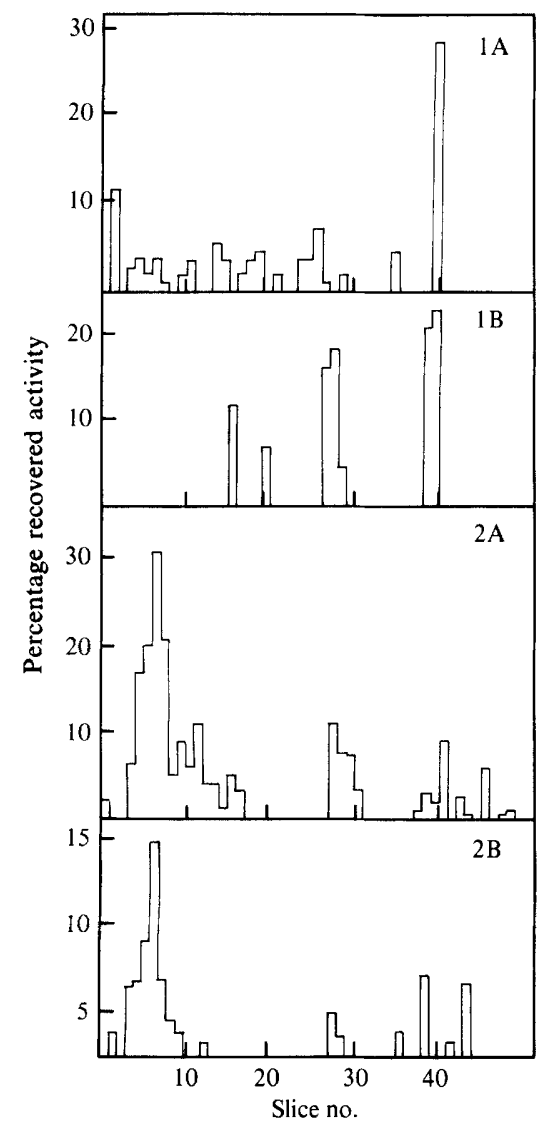

Fig. 3

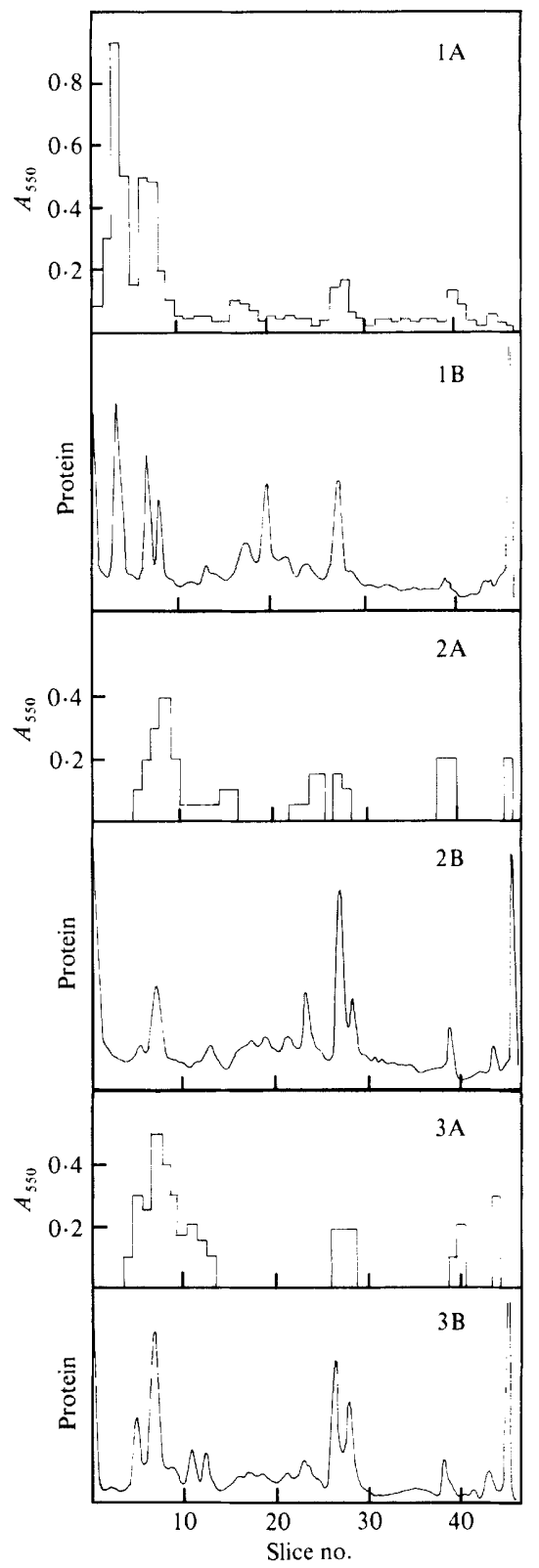

Fig. 4

Fig. 3. Binding to Avicel of CM-cellulase activity in culture supernatants. A culture was grown with $0.1 \%$ Avicel and samples were taken at $3 \mathrm{~d}$ (panel 1) and $9 \mathrm{~d}$ (panel 2). Cells and residual Avicel were removed by centrifugation. One half of the supernatant was concentrated 100 -fold by ultrafiltration. The other half was shaken gently with $5 \%$ Avicel for $20 \mathrm{~h}$ at $30^{\circ} \mathrm{C}$. The Avicel was removed by filtration and the filtrate concentrated 100 -fold by ultrafiltration. Both samples were screened by PAGE as described in the legend to Fig. 1 ; In each case, A shows the sample treated with Avicel, and B the untreated sample.

Fig. 4. CM-cellulase activities in culture supernatants at different stages of growth. A culture was grown with $0 \cdot 1 \%$ Avicel. At $3 \mathrm{~d}$ (panel 1), $6 \mathrm{~d}$ (panel 2) and $9 \mathrm{~d}$ (panel 3), samples were removed and treated as described in the legend to Fig. 1. In each case, A shows CM-cellulase activity, and B the protein scan (relative units). 


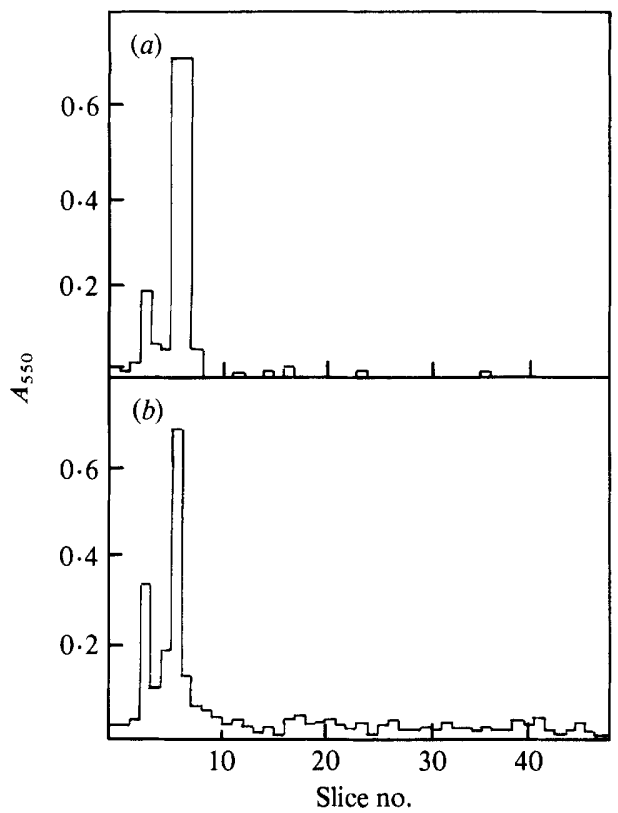

Fig. 5. Substrate-bound CM-cellulase activities in Avicel cultures. Cultures were grown for $6 \mathrm{~d}$. The residual Avicel was washed, then the bound $\mathrm{CM}$-cellulase activities were removed with guanidine. $\mathrm{HCl}$ was measured with 3,5-dinitrosalicylic acid; 1 unit of activity causes the release of $1 \mu \mathrm{g}$ equivalent of glucose $\min ^{-1}$ at $37^{\circ} \mathrm{C}$.

\section{Table 1. Enzyme activities in C. fimi culture supernatants}

The culture supernatants were not concentrated. Proteinase activity was standardized with Sigma collagenase; 1 unit of activity releases $1 \mu \mathrm{mol} \mathrm{L}$-leucine in $5 \mathrm{~h}$ at $\mathrm{pH} 7.4$ and $37^{\circ} \mathrm{C}$. CM-cellulase activity was measured with 3,5-dinitrosalycylic acid; 1 unit of activity causes the release of $1 \mu \mathrm{g}$ of reducing glucose $\min ^{-1}$ at $37^{\circ} \mathrm{C}$.

\section{Growth substrate}

$$
\begin{aligned}
& 0.1 \% \text { Avicel } \\
& 0.1 \% \text { Avicel }+1 \% \text { glucose } \\
& 0.1 \% \text { CM-cellulose } \\
& 0.1 \% \text { CM-cellulose }+1 \% \text { glucose } \\
& 1 \% \text { Glucose } \\
& 1 \% \text { Cellobiose }
\end{aligned}
$$

Proteinase activity (units of collagenase equivalents $\mathrm{ml}^{-1}$ )
$1 \cdot 8$
$0 \cdot 21$
9.6
$0 \cdot 26$
$0 \cdot 18$
$0 \cdot 21$

\section{CM-cellulase activity} (units $\mathrm{ml}^{-1}$ )

130
0
90
0
0
0

The monoclonal antibodies showed marked specificity for one or more of the cellulase bands (Table 2). The binding of a single monoclonal antibody to more than one fraction indicated that these fractions shared similar or identical antigenic determinants. It was unlikely that this relatedness was attributable to cross-contamination of adjacent bands. Monoclonals A2/24.22.10 and A2/36.17.2 reacted only with band 6/7, whereas A2/25.29.5 reacted with both fractions $6 / 7$ and 8 ; A2/41.8 15 bound to fraction 8 but not to fraction $6 / 7$. The wide crossreactivity of $\mathrm{A} 2 / 37.9 .18$, which bound to all of the fractions except band 2, was particularly interesting because it indicates a conserved structure, perhaps related to the site of enzyme activity. Each of the monoclonals shown was tested on several unrelated antigens (bovine serum albumin; keyhole limpet haemocyanin) and showed no non-specific binding. Assay conditions were optimized using rabbit antiserum to detect the individual cellulases bound to the plates. The anti-mouse Ig second antibody was used under conditions previously shown to detect nanogram levels of mouse Ig. 
Table 2. Binding of monoclonal antibodies to $C M$-cellulase isolates from non-denaturing $P A G E$ bands

\begin{tabular}{lrrrrrrrrr} 
& \multicolumn{7}{c}{$\begin{array}{c}\text { 125 I-Labelled rabbit } F\left(\mathrm{ab}^{\prime}\right)_{2} \text { anti-mouse } \\
\text { Ig bound per well (c.p.m.) }\end{array}$} \\
$\begin{array}{l}\text { Monoclonal } \\
\text { antibody }\end{array}$ & Band $^{*}$ & $\ldots$ & 1 & 2 & 3 & $4 / 5$ & $6 / 7$ & 8 & 10 \\
A2/23.11.32 & & 100 & 100 & 120 & 130 & 1170 & 155 & 130 \\
A2/24.22.10 & & 110 & 110 & 135 & 145 & 3600 & 415 & 135 \\
A2/25.29.5 & 150 & 110 & 140 & 100 & 6610 & 2200 & 180 \\
A2/36.17.2 & 280 & 210 & 260 & 200 & 8800 & 500 & 475 \\
A2/37.9.18 & 1095 & 300 & 1100 & 3630 & 2725 & 5160 & 1440 \\
A2/41.8.15 & 215 & 90 & 200 & 645 & 320 & 1530 & 190
\end{tabular}

* The bands corresponded to regions of CM-cellulase activity in a non-denaturing gel, numbered from the origin so that bands 1,2 and 3 were the slowest moving.

Immunoadsorbent columns were known to bind the cellulase activity in $C$. fimi culture supernatants quite specifically (Whittle et al., 1982). An immunoadsorbent column prepared with monoclonal antibody $\mathrm{A} 2 / 36.17 .2$ retained $55 \%$ of the CM-cellulase activity from the $3 \mathrm{~d}$ supernatant of a $0.1 \%$ Avicel culture and $25 \%$ of the activity from the $9 \mathrm{~d}$ supernatant. The adsorbed material was heterogeneous (Fig. 6), indicating that several polypeptides with CM-cellulase activity shared the $6 / 7$ determinant recognized by the monoclonal antibody, or that other polypeptides associated with a polypeptide(s) carrying the determinant.

\section{DISCUSSION}

The cellulase system of $C$. fimi appears to be complex. Supernatants of cultures grown with Avicel as carbon source contain up to 10 components with CM-cellulase activity, as defined by the bands of activity recovered from non-denaturing polyacrylamide gels. The activity profiles vary with substrate and even from culture to culture with the same substrate (compare Figs 1 and 4). If each band of activity were to represent a discrete gene product, successful reconstruction of the system by gene cloning would be an awesome task.

However, the results presented in this paper make it clear that the $C$. fimi cellulase system is much simpler than indicated by the activity profiles; they lead us to propose the following working outline for the system. It contains no more than three or four components, at least two of which are glycosylated. These enzymes bind very strongly to Avicel, and are stabilized by this substrate. Once the substrate concentration falls below a certain level, newly synthesized enzymes do not bind to the residual substrate and some bound enzyme is released by digestion of the substrate or by proteolysis. Enzyme which is free in the supernatant is unstable and can be altered by proteolysis and by de-glycosylation. This results in a diversity of products, some of which are still enzymically active but reduced in their substrate affinity. These alterations cause the variations in the activity profiles of the supernatants from different cultures, as well as the changes seen during incubation of a single culture. All the results are consistent with this proposal. Three cellulases have been described for a different strain of $C$. fimi: two of these are glycosylated and bind strongly to cellulose (Beguin \& Eisen, 1978). The cellulase system from Pseudomonas fluorescens var. cellulosa also contains three cellulases, and these are all glycosylated (Yamane et al., 1970).

The immunological data are consistent with the conclusion that the diverse CM-cellulase activities in the supernatants are determined by a small number of structural genes. The extracellular cellulase system of Streptomyces antibioticus may be similar in this regard. This organism produces five electrophoretically distinct endocellulases, three of which are immunologically related (Enger \& Sleeper, 1965). 


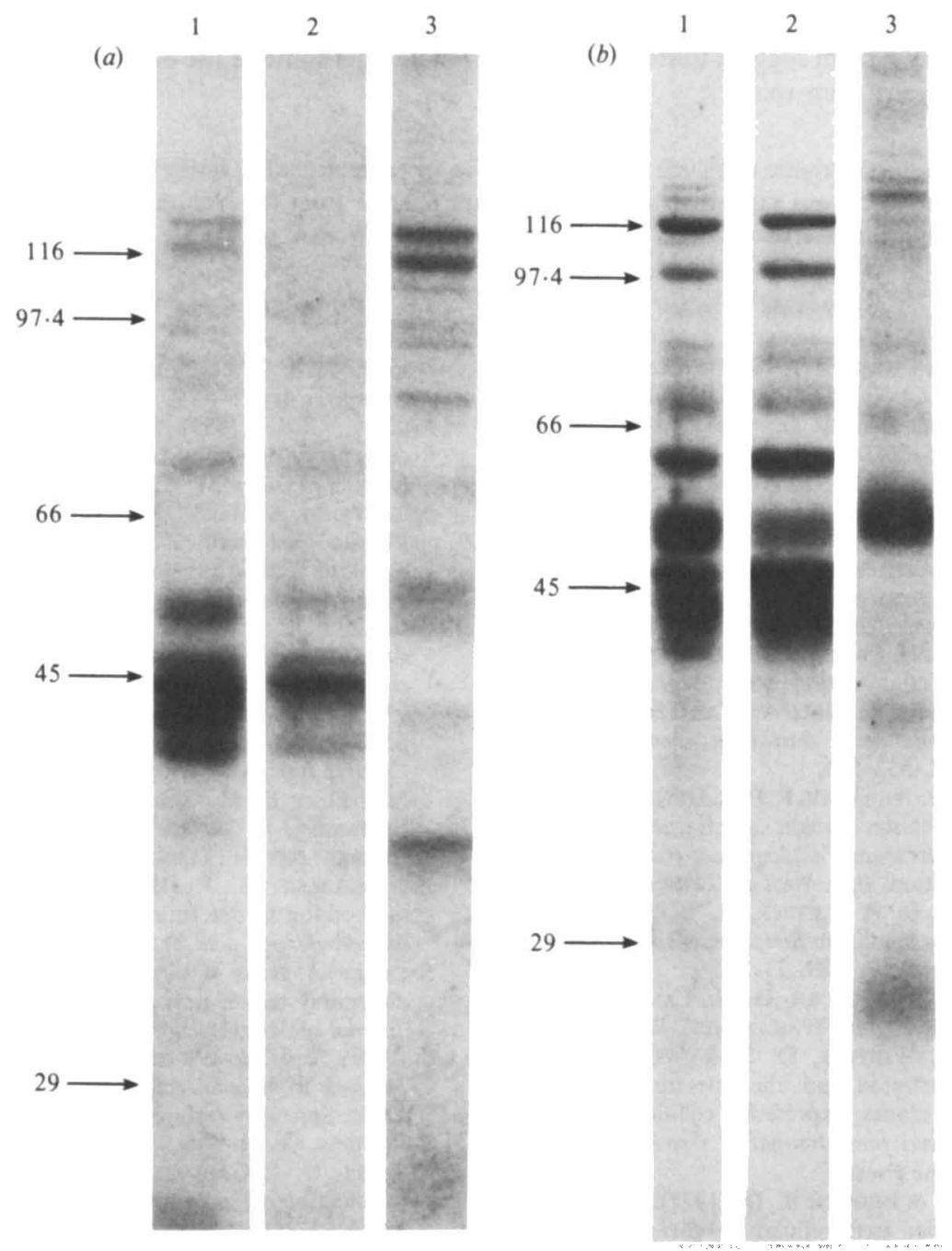

Fig. 6. Immunoadsorption of CM-cellulase activity. Polypeptides bound by an immunoadsorbent column prepared with monoclonal antibody A2/36.17.2 (see Methods) were analysed by SDS-PAGE ( $10 \%$ polyacrylamide). (a) $3 \mathrm{~d}$ culture supernatant; (b) $9 \mathrm{~d}$ culture supernatant. Lane 1 , total supernatant; lane 2, unbound fraction; lane 3, bound fraction. Arrows indicate molecular weight standards (kDal).

In the accompanying paper (Gilkes et al., 1984) we describe the isolation and characterization of further clones of $E$. coli carrying $C$. fimi cellulase genes. The clones characterized so far are of only three types, each of which determines the synthesis in $E$. coli of a different cellulase. This observation lends weight to the conclusion that the cellulase complex of $C$. fimi is determined by very few structural genes.

It is possible that the substrate-bound enzymes represent the most active forms of the $C$. fimi cellulases. We are determining the specific activities of the various cellulases obtainable from this organism, and we are attempting to determine the relationship of the bound enzymes to both the free enzymes and to those synthesized by the $E$. coli clones. The extent and nature of glycosylation of the various components is an especially intriguing point, since electrophoretic mobility is known to be affected by glycosylation. We are also determining the nature and function of the protein bound to the substrate in $5 \%$ Avicel cultures which does not have CMcellulase activity. 
The cellulase systems from other micro-organisms frequently appear complex. The properties of the $C$. fimi system suggest that the complexity of at least some of the other systems may well be more apparent than real.

We wish to thank Brigitte Gerhardt and Valerie Raffle for expert technical assistance in the early stages of this work. This research was supported by Strategic Grant 67-0941 from the Natural Sciences and Engineering Research Council of Canada to D.G.K., R.C.M. and R.A.J.W.

\section{REFERENCES}

Beguin, P. \& Eisen, H. (1978). Purification and partial characterization of three extracellular cellulases from Cellulomonas sp. European Journal of Biochemistry 87, 525-531.

Berghem, L. E. R., Pettersson, L. G. \& AxioFREDRICKSSON, U.-B. (1976). The mechanism of enzymatic cellulose degradation. Purification and some properties of two different 1,4- $\beta$-glucan glucanohydrolases from Trichoderma viride. European Journal of Biochemistry 61, 621-630.

Chol, W. Y., HAGGeTt, K. D. \& DunN, N. W. (1978). Isolation of a cotton wool degrading strain of Cellulomonas: mutants with altered ability to degrade cotton wool. Australian Journal of Biological Science 31, 553-564.

Choudhury, N., Gray, P. P. \& DuNN, N. W. (1980). Saccharification of sugar cane bagasse by an enzyme preparation from Cellulomonas: resistance to product inhibition. Biotechnology Letters 2, 427-428.

ENGer, M. D. \& SleEPer, B. P. (1965). Multiple cellulase system from Streptomyces antibioticus. Journal of Bacteriology 89, 23-27.

Gilkes, N. R., KILBURN, D. G., LANGSFORD, M. L., Miller, R. C., JR, WakarchuK, W. W., Warren, R. A. J., Whittle, D. J. \& Wong, W. K. R. (1984). Isolation and characterization of Escherichia coli clones expressing cellulase genes from Cellulomonas fimi. Journal of General Microbiology 130, (in the Press).

Gum, E. K. \& Brown, R. D. (1977). Comparison of four purified extracellular 1,4- $\beta$-D-glucan cellobiohydrolase enzymes from Trichoderma viride. Biochimica et biophysica acta 492, 225-231.

Haggett, K. D., Gray, P. P. \& DunN, N. W. (1979). Crystalline cellulose degradation by a strain of Cellulomonas and its mutant derivatives. European Journal of Applied Microbiology and Biotechnology 8, 183-190.

Jovin, T., Chrambach, A. \& Naughton, M. A. (1964). An apparatus for temperature-regulated polyacrylamide gel electrophoresis. Analytical Biochemistry 9, 351-369.

LAEMMLI, U. K. (1970). Cleavage of structural proteins during assembly of the head of bacteriophage T4. Nature, London 277, 680-685.

McGuckin, W. F. \& McKenzie, B. F. (1958). An improved periodic acid fuchsin sulfite staining method for evaluation of glycoproteins. Clinical Chemistry 4, 476-483.

MilleR, G. L. (1959). Use of dinitrosalicylic acid reagent for determination of reducing sugars. Analytical Chemistry 31, 426-428.

Millett, M. A., Baker, A. J. \& Satter, L. D. (1976). Physical and chemical pretreatments for enhancing cellulose saccharification. Biotechnology and Bioengineering Symposium 6, 125-153.

O'Farrell, P. H. (1975). High resolution two-dimensional electrophoresis of proteins. Journal of Biological Chemistry 250, 4007-4021.

OI, V. T. \& HERZENBERG, L. (1980). Immunoglobulinproducing hybrid cell lines. In Selected Methods in Cellular Immunology, pp. 351-372. Edited by B. B. Mishell \& S. M. Shiigi. San Francisco: W. H. Freeman.

RinderkneCht, H., Geokas, M. C., Silverman, P. \& HAVERBACK, B. J. (1968). A new ultrasensitive method for the determination of proteolytic activity. Clinica chimica acta 21, 197-203.

SAdDler, J. N. \& Khan, A. W. (1981). Cellulolytic enzyme system of Acetivibrio cellulolyticus. Canadian Journal of Microbiology 27, 288-294.

Schleif, R. F. \& Wensink, P. C. (1981). Practical Methods in Molecular Biology, pp. xiii +220 . New York: Springer-Verlag.

Schneider, C., Newman, R. A., Sutherland, D. R., Asser, U. \& Greaves, M. F. (1982). A one-step purification of membrane proteins using a high efficiency immunomatrix. Journal of Biological Chemistry 257, 10766-10769.

Stewart, B. J. \& Leatherwood, J. M. (1976). Derepressed synthesis of cellulase by Cellulomonas. Journal of Bacteriology 128, 609-615.

Whittle, D. J., Kilburn, D. G., WarRen, R. A. J. \& MILLER, R. C., JR (1982). Molecular cloning of a Cellulomonas fimi cellulase gene in Escherichia coli. Gene 17, 139-145.

Yamane, K., Suzuki, H. \& Nisizawa, K. (1970). Purification and properties of extracellular and cellbound cellulase components of Pseudomonas fluorescens var. cellulosa. Journal of Biochemistry 67, 19-35.

Zacharius, R. M., Zell, T. E., Morrison, J. H. \& WoODLOCK, J. J. (1969). Glycoprotein staining following electrophoresis on acrylamide gels. Analytical Biochemistry 30, 148-152. 